Food, Dairy and Home Economic Research

http:/www.journals.zu.edu.eg/journalDisplay.aspx?Journalld=1\&queryType=Master

\title{
CHARACTERIZATION OF MILK CLOTTING PROPERTIES OF ADULT CATTLE RENNET MODIFIED WITH Moringa oleifera SEEDS AND ITS SUITABILITY AS CALF RENNET ALTERNATIVE IN CHEESE MAKING
}

\author{
Hesham A. Ismail \\ Dairy Sci. Dept., Fac. Agric., New Valley Univ., Egypt
}

Received: 08/04/2019; Accepted: 12/05/2019

\begin{abstract}
The present study focused on the mixing of adult cattle rennet with Moringa seeds during the extraction process to improve its strength and use it as an alternative for the calf rennet in cheese production. The Moringa oleifera seeds powder were mixed with adult cattle rennet at a ratio of $2 \%$. Crude and partially purified extracts (using ammonium sulphate $60 \%$ concentration) were used. The study include six different milk coagulants; adult cattle rennet extract (ARE), mix of adult cattle rennet with Moringa seeds (AME), partially purified adult cattle rennet extract (ARP), partially purified adult rennet mixed with Moringa seeds (AMP), commercial rennet (RRE) and calf rennet extract (CRE). The flocculation time, clotting time, clotting activity, proteolytic activity, the optimum $\mathrm{pH}$ and temperature for clotting activity, curdling quality (RCQ) and protein profile of curd formed were determined (SDS-PAGE). The physical properties include water release (WR) and water holding capacity (WHC), yield and sensory attributes of Domiati cheese made by using different coagulant extracts were estimated. The results showed that CRE has shorter flocculation and clotting time and higher milk clotting activity but ARE had the opposite, in the midst were treatments AME, ARP and AMP. The pH range of 5.5 to 6.5 and temperature between $50-60^{\circ} \mathrm{C}$ were suitable for milk clotting activity of milk coagulants. The best (RCQ) was found to be for the curd formatted by CRE, AMP, ARP and RRE. Physical properties gave the lowest (WR) and highest (WHC) in CRE curd cheese, followed by AMP, RRE, ARP and AME cheese, whilst it was observed the contrary in ARE. Electrophoretic patterns show that the levels of degradation $\alpha$ s-casein, $\kappa$-casein and $\beta$-casein differed with milk coagulant types. Using Moringa seeds and partially purified by ammonium sulphate improved yield and cheese sensory with characteristic; coherent texture and creamy taste. In conclusion mixing of adult cattle rennet with Moringa seeds powder during the extraction process and/ or partially purified gave an opportunity to be used as an alternative to calf rennet in cheese making.
\end{abstract}

Key words: Moringa oleifera seeds, adult cattle rennet, calf rennet; ammonium sulphate, commercial rennet, curd properties, Domiati cheese, sensory evaluation.

\section{INTRODUCTION}

Coagulation of milk is a basic step in the manufacture of most cheeses and can be achieved by a number of proteolytic enzymes from various sources, such as different animal rennet, microbial proteinases and proteinases extracted from fruits and plants (Vioque et al., 2000). Animal rennet is traditionally manufactured by extraction from the fourth stomach abomasum. The enzymes extracted from abomasum consist mainly of two enzymes maxing chymosin and pepsin. The relative proportion of the two enzymes varies with the age of the animal at slaughtering time. Calf rennet, originally obtained from the abomasum of recent born ruminant calves contains chymosin as the major, milk-clotting components of 88 to $94 \%$, and pepsin to a lesser extent but adult cattle rennet may contain 90 to $94 \%$ of pepsin and only 6 to $10 \%$ of chymosin (Broome and Limsowtin, 1998). Chymosin has been extensively used in

\footnotetext{
* Corresponding author: Tel. : +201092550623

E-mail address: h_alshnety@yahoo.com
} 
the cheese making to produce a stable curd with good flavour due to its high specificity for cleaving the k-casein Phe 105- Met 106 bond (Rao et al., 1998). Whereas pepsin is much less specific and hydrolyses casein coupled with certain beneficial effect during ripening of cheese (Papoff et al. 2004). Compared to chymosin, pepsin has number of difficulties such as longer clotting time, forming a soft curd, and an undesirable taste. The clotting activity affects the properties of the curd, such as firmness or softness, during processing (Walstra et al., 2005). However, the worldwide increase in cheese production, coupled with reduced supply and increasing prices of calf rennet, some religious factors (Islam and Judaism) and others related to vegetarianism of some consumers, have encouraged the search for alternatives sources of milk-coagulants to be used as appropriate rennet substitutes. Research effects have been directed for new proteases with high specific milk-clotting activity and low general proteolytic activity to resemble animal rennet properties (Shah et al., 2014). Accordingly, some plant proteases similar chymosin are able to cleave few sites at $\alpha \mathrm{s}_{1}$ and $\beta$ caseins, which may occur in maintaining the micelles stability (Silva et al., 2002). Pontual et al. (2012) confirmed that Moringa oleifera is a new source of proteases with potential use for cheese production on account of promoting extensive hydrolysis of k-casein and low degradation of $\alpha_{\mathrm{s}}$ - and $\beta$-caseins compared with other plant coagulants. It has been concluded that Moringa oleifera plant is an exciting source of milk clotting enzymes such as aspartic enzyme in different parts (Pontual et al., 2012). Agreeing to Tajalsir et al. (2014), the milk clotting activity of $M$. oleifera was only found in the seeds extract while the other parts were either deficient or has very low milk clotting activity. Moringa oleifera seeds extract are rich in proteases having specific clotting activity 200 times higher than that of flower extract. Approving to these results, it is concluded that the seed extract of $M$. oleifera generates suitable milk clotting activity for cheese making (Sánchez-Muñoz et al., 2017). Mahami et al. (2012) proved that Moringa oleifera seed extracts used to prepare cottage cheese with increasing in the yield of cheese. On the same line, sensorial properties including texture, appearance, flavour, taste and colour of the produced cheeses were improved by used
Moringa oleifera seeds as coagulant (Orhevba and Taiwo, 2016).

Precipitation with ammonium sulphate is extensively used in processing of biological products, such as proteins. According to Kent (1999) protein purification using ammonium sulphate has three main advantages; it is a rapid and inexpensive method, it does not affect the structure and function of proteins and the salt can be easily removed from the protein solution by dialysis. Sedimentation with ammonium sulphate could be an effective way to produce substantial amounts of active purified proteases, and concentrated the enzyme to a workable volume that could efficiently be used for milk coagulation in cheese making industry (Tajalsir et al., 2014).

The present study was undertaken to evaluate the milk clotting properties of crude and partially purified adult rennet modified by mixing with Moringa oleifera seeds during the process of extraction. The suitability of the resultant extracts as calf rennet alternatives in cheese making was given considerable attention

\section{MATERIALS AND METHODS}

This study was carried out during November 2017 to August 2018 in the Dairy Technology laboratory of Dairy Department, Agricultural Faculty, New Valley University, Egypt.

\section{Materials}

Fresh abomasum of adult cattle and calf were brought from one butcher in El-kharga City, New Valley Governorate, Egypt. The dried pods in Moringa oleifera were collected from the local farm in El-Kharga City, New Valley Governorate, Egypt. Raw cow's milk (total solid $12.8 \%, 3.5 \%$ protein, $3.7 \%$ fat, $5.0 \%$ lactose and $\mathrm{pH}$ 6.7) was obtained from private animal farm in El-kharga City, New Valley Governorate, Egypt. Low heat skim milk powder imported from USA (Dairy America California). Commercial liquid calf rennet was purchased from Mifad, Misr Food Additives, Egypt. Sodium chloride, ammonium sulphate, sodium acetate, and other chemicals were purchased from Gomhoria Company, Assiut Governorate, Egypt. 


\section{Experimental Procedure}

\section{Preparation of experimental crude rennet extracts}

Rennet of adult cattle (ARE) and rennet of calf (CRE) extracts were prepared according to the method of Ahmed et al. (2013), with some modification. After removing the internal contents, abomasum tissues were cleaned with tap water, as well veins and fat contents were external removed. Then they were inflated with air just like a balloon, $20 \mathrm{~g}$ sodium chloride were externally sprayed and dried in an open air for about one week followed by storage for one month. The abomasum was then cut into thin pieces. Weight $(100 \mathrm{~g})$ of dried abomasum was soaked in $1000 \mathrm{ml}$ solution containing $(60 \mathrm{~g}$ sodium chloride, $2 \mathrm{~g}$ sodium benzoate, $0.5 \mathrm{~g}$ sorbic acid in distilled water), and adjust the $\mathrm{pH}$ to 5.4. The solution was stored at room temperature for one week with daily stirring. The extract was filtered through muslin cloth, clarification by addition $8 \mathrm{~g}$ aluminum potassium sulphate and free enzyme by addition $16 \mathrm{~g}$ disodium phosphate ( $10 \%$ solution) with stirring for $3 \mathrm{~min}$. The extract was again filtered through Whatman filter paper No. 1 and centrifuged at a speed of $5000 \mathrm{rpm}$ for $20 \mathrm{~min}$, then the pellet was discarded while the supernatant was collected and designate as crude enzyme extract.

\section{Preparation of crude adult cattle rennet modified by Moringa seed}

Manually the seeds were removed from pods and removed seed coats from seeds to obtain clean seed kernels. The white kernels were then crushed to a powder using an electric grinder to obtain a fine powder. About $20 \mathrm{~g}$ of seeds powder was blended in $1000 \mathrm{ml}$ crude enzyme of adult cattle rennet. Then it stirred rapidly for sixty minutes, after every interval the samples were allowed to rest for 60 minutes and were filtered through Whatman filter paper No1. Then centrifuge at a speed of $5000 \mathrm{rpm}$ for $20 \mathrm{~min}$. The pellet was discarded and the supernatant was collected designate crude enzyme mix of adult cattle rennet with Moringa seeds (AME).

\section{Partial purification of crude adult cattle rennet extracts}

The crude enzyme of adult cattle rennet without and with added Moringa oleifera seeds powder were partially purified by ammonium sulphate precipitation technique. The crude enzyme extract $(50 \mathrm{ml})$ was partially purified by adding of solid ammonium sulphate to $60 \%$ concentration at $4^{\circ} \mathrm{C}$ for $30 \mathrm{~min}$ according to Ahmed et al. (2009), with some modifications. The sedimentary protein was collected by centrifugation at $5000 \mathrm{rpm}$ at room temperature for $20 \mathrm{~min}$. The supernatant was discarded while the precipitate was re-dissolved in $5 \mathrm{ml}$ of $0.1 \mathrm{M}$ sodium acetate buffer ( $\mathrm{pH} 5$ ), and then dialyzed overnight at $4^{\circ} \mathrm{C}$ against the same buffer with several change of the dialysis buffer. The extracts obtained were named ARP and AMP for partially purified for adult cattle rennet without and with added Moringa seeds powder, respectively.

\section{Methods of Analysis}

\section{Determination of rennet flocculation and clotting times}

The rennet flocculation time (RFT) is the time period between the additions of coagulant enzyme and the appearance of flakes visible to the naked eye (Kappeler et al., 2006). The rennet clotting time (RCT) is the time period between the application of the coagulant enzyme to the milk at $35^{\circ} \mathrm{C}$ and the aggregation of milk. The rennet curdling quality (RCQ) is evaluated after the curd formed and tipped out into Petri dish to assay the appearance and firmness of the curd and the appearance of the whey as investigated by Kuchtík et al. (2008).

\section{Determination of milk-clotting activity (MCA)}

The milk clotting activity of coagulant enzyme was performed as described by Badgujar and Mahajan (2009). The enzyme extract $(0.2 \mathrm{ml})$ was added to $2 \mathrm{ml}$ of substrate solution of reconstitute $10 \%$ skim milk powder with $0.01 \mathrm{M} \mathrm{CaCl}_{2}$. The time needed for the formation of curd fragment at $35^{\circ} \mathrm{C}$ was measured. Milk clotting activity is expressed in term of Soxhlet unit.

Where:

$$
\text { Soxhlet units }(\mathrm{U} / \mathrm{ml})=\frac{\mathrm{M} \times 2400}{\mathrm{E} \times \mathrm{t}}
$$

M: the volume of substrate $(\mathrm{ml})$.

E: the amount of enzyme extract $(\mathrm{ml})$.

$\mathrm{t}:$ the clotting time $(\mathrm{sec})$. 
Determination protein content and proteolytic activity (PA)

Total protein was determined in milk coagulants by the standard micro- Kjeldahl method of the AOAC (1995). A nitrogen conversion factor of 6.25 was used for calculation of protein. Proteolytic activity of coagulant extracts was evaluated by comparing non protein nitrogen (NPN) contents of raw reconstituted milk and rennet coagulated milk (Ahmed et al., 2013). Briefly $0.2 \mathrm{ml}$ of enzyme extract was added to $2 \mathrm{ml}$ of $10 \%(\mathrm{~W} / \mathrm{W})$ of reconstituted skim-milk powder containing 0.01 $\mathrm{M}$ calcium chloride and incubated at $35^{\circ} \mathrm{C}$ for $40 \mathrm{~min}$. Non-protein nitrogen (NPN) content was determined according to the method of International Dairy Federation (IDF, 1993). The specific activity was determined by dividing the MCA on protein content (mg).

Optimum temperature and $\mathrm{pH}$ for milkclotting activity

Aliquots of reconstituted spray-dried skim milk (10 g in $100 \mathrm{ml} 0.01 \mathrm{M}$ calcium chloride) were adjusting to different $\mathrm{pH}$ values $(5.5,6.0$, 6.5, 7.0, 7.5 and 8.0), and incubated at different temperatures $(30,35,40,4550,55,60,65$ and $70^{\circ} \mathrm{C}$ ) . Adjusted to the desired $\mathrm{pH}$ with $0.1 \mathrm{M}$ $\mathrm{HCl}$ or $\mathrm{Na} \mathrm{OH}$ and incubated at the desired temperature, according to Corrons et al. (2012).

\section{Electrophoretic Analysis (SDS-PAGE)}

Soluble proteins were extracted from curd formed by ARE, AME, ARP, AMP, RRE and CRE coagulants. Crushing $1.0 \mathrm{~g}$ of the sample in $1 \mathrm{ml}$ of extraction buffer $(0.1 \mathrm{M}$ Tris-HCl, $2 \mathrm{mM}$ EDTA, 2\% glutathione, $\mathrm{pH}$ 7.8). The mixture was centrifuged for $20 \mathrm{~min}$ at $13000 \mathrm{rpm}$ and $4^{\circ} \mathrm{C}$. A mixture of the supernatant and the sample application buffer $(2.5 \mathrm{mM}$ Tris- $\mathrm{HCl} \mathrm{pH}$ 6.8, $10.0 \%$ glycerol, $4.0 \%$ SDS, $\quad 0.02 \%$ bromophenol blue and 10\% mercaptoethanol) was prepared with a ratio of (1:1) and then, the mixtures were incubated in water path at $100^{\circ} \mathrm{C}$ for five min. for protein denaturation, and then loaded in the electrophoresis apparatus. Electrophoresis was carried out according to the method of (Laemmli, 1970). Electrophoresis was performed in a vertical slab gel apparatus "SE 600 , vertical slab gel" at $10^{\circ} \mathrm{C}$ in a $12 \%$ polyacrylamide separating gel, 3.5\% stacking gel, denaturing conditions using $1 \%$ sodium dodecyl sulphate, at $30 \mathrm{~mA}$, until the dye band reached the bottom of the separating gel. For the detection of protein bands, the gels were stained with commassie brillant blue $\mathrm{R}$ for one hour. Then, the destining was performed by repeated immersion in a mixture of methanol/ acetic acid/water (1: $1: 8$, by volume).

\section{Cheese making}

Domiati cheese treatments were made according to Abou-Donia (1986) with some modulation. Fresh cow milk (3.7\% fat and 3.5\% protein) was heated to $72^{\circ} \mathrm{C}$ for $2 \mathrm{~min}$. and then cooled to $45^{\circ} \mathrm{C}$, followed by addition of skim milk powder, $\mathrm{CaCl}_{2}$ and $\mathrm{NaCl}$ at the rate of $5 \%$, $0.02 \%$ and $6 \%$ respectively. The milk was divided into six equal portions .Milk coagulants; ARE, AME, ARP, AMP and CRE were added at the ratio of $2 \mathrm{ml} / \mathrm{l}$ milk and that of RRE concentration was $0.6 \mathrm{ml} / 1$ of milk. The resultant cheeses were refereed as called ARE, AME, ARP, AMP, CRE and RRE cheese. The milk was mixed and left until coagulation was completed. After coagulation; the curd was cut with a sharp knife. The curd was poured into small stainless steel holes molds overnight. Cheese samples were taken for analyses after one day.

\section{Estimation of cheese curd properties}

Water release (WR) analyses were performed using the method reported by Lemes et al. (2016). $10 \mathrm{~g}$ of curd cheese were centrifuged at $5000 \mathrm{rpm}$ for $20 \mathrm{~min}$ at room temperature. Water release (WR) was defined as follows:

WR $(\%)=100$ (Initial weight - final weight) / (initial weight).

Water holding capacity (WHC) was calculated according to Farnsworth et al. (2006).

$$
\begin{gathered}
\text { WHC (\%) }=100 \text { (curd cheese weight- serum } \\
\text { weight) / curd cheese weight }
\end{gathered}
$$

\section{Yield calculation}

Cheese yields were calculated as a weight of cheese divided by weight of milk expressed as a percentage (Nelson et al., 2004). 


\section{Sensory attributes}

Organoleptic properties of fresh Domiati cheese were assessed by taste panel included mainly researchers and graduate students of the Dairy Science Department, Faculty of Agriculture, New Valley University. Fresh cheese samples were evaluated for flavour (50 points), body and texture (40 points) and appearance (10 points) according to Bodyfelt et al. (1988).

\section{Statistical Analysis}

SPSS (Version 11.0) software was used for all statically analysis. The effects of crude extract, purified enzyme, commercial rennet and calf rennet on curd properties yield and sensory attributes of Domiati cheese were estimated using analysis of variance (ANOVA). Significant means were compared using Duncan's test on the level of $\mathrm{P} \leq 0.05$.

\section{RESULTS AND DISCUSSION}

\section{Flocculation and Clotting Times}

The coagulation properties of milk are of great importance as they influence cheese yield and quality. Fig. 1 clears that the flocculation time (RFT) of ARE, AME, ARP, AMP, RRE and CRE was found to be $169.67,133.67$, $122.67,82.33, \quad 56.00$ and 28.00 seconds respectively. Clotting time (RCT) was 217, $177.67,152.00,119.33,83.67$ and 53.67 seconds, respectively. From these results, it could be concluded that crude and partially purified adult cattle extract containing Moringa oleifera seeds had shorter flocculation and clotting time compared with the corresponding extract prepares without Moringa seeds. Shorter flocculation and clotting time were found to be for the partially purified adult rennet extract with added Moringa seeds. Whereas their values were comparable to those of both calf rennet extract and commercial rennet. These results could be explained on the basis that Moringa oleifera seeds contained one or more enzymes with rennet like activity (Sánchez-Muñoz et al., 2017). Partial purification using ammonium sulphate has led to more concentrated milk clotting proteases. This may be due to molecular rearrangements in protein structure can lead to increase of enzyme activity (Purich, 2010). Moreover Castillo et al. (2002) showed that the use of calf rennet as milk coagulant led to faster increase in reflectance due to a higher specific activity to $\kappa$-casein. Short clotting time is imported in the manufacture of various type of cheeses, such as soft, semi-hard and hard cheese, could be due to increase in rate of aggregation as a result of decrease in volume of the aqueous phase (Mehaia and El-Khadragy 1998).

\section{Milk Clotting Activity (MCA)}

Milk clotting activity (MCA) is the most important property of proteases used in cheese production. Accordingly, the highest milk clotting activity (MCA) was recorded for the CRE as illustrated in Table 1. While, ARE had the lowest milk clotting activity. This indicated that the clotting activity is related to the enzyme's capacity to calving k-casein at the Phe105-Met106 peptide bond, which is the starting point of enzymatic cheese making. Guinee and Wilkinson (1992) showed that the clotting activity of rennet relies on its ability to degrade casein micelles. The action is dependent on the chymosin and pepsin content of the rennet. Therefore, this suggested that the content of pepsin was higher in adult cattle rennet extract (Broome and Limsowtin, 1998), compared with rennet extracted from younger calves containing higher chymosin (Akin, 1996). Normally commercial rennet contains $70 \%$ chymosin and $30 \%$ pepsin. The standard ratio is approximately $80 \%$ chymosin and $20 \%$ pepsin (Irigoyen et al., 2001). However, adult cattle rennet may contain up to 90 to $94 \%$ of pepsin and only 6 to $10 \%$ of chymosin (Broome and Limsowtin, 1998). Good quality rennet should possess a constant clotting activity and contain no other enzymes than chymosin (Çakmakçi and Boroğlu, 2004). It was also observed from Table 1 that the milk clotting activity increased nonetheless decreasing clotting time with mixing adult cattle rennet with Moringa seeds powder during the process of extraction, indicating that $M$. oleifera is an exciting source of milk clotting enzyme with an excellent clotting property (Sánchez-Muñoz et al., 2017). Partial purification by ammonium 


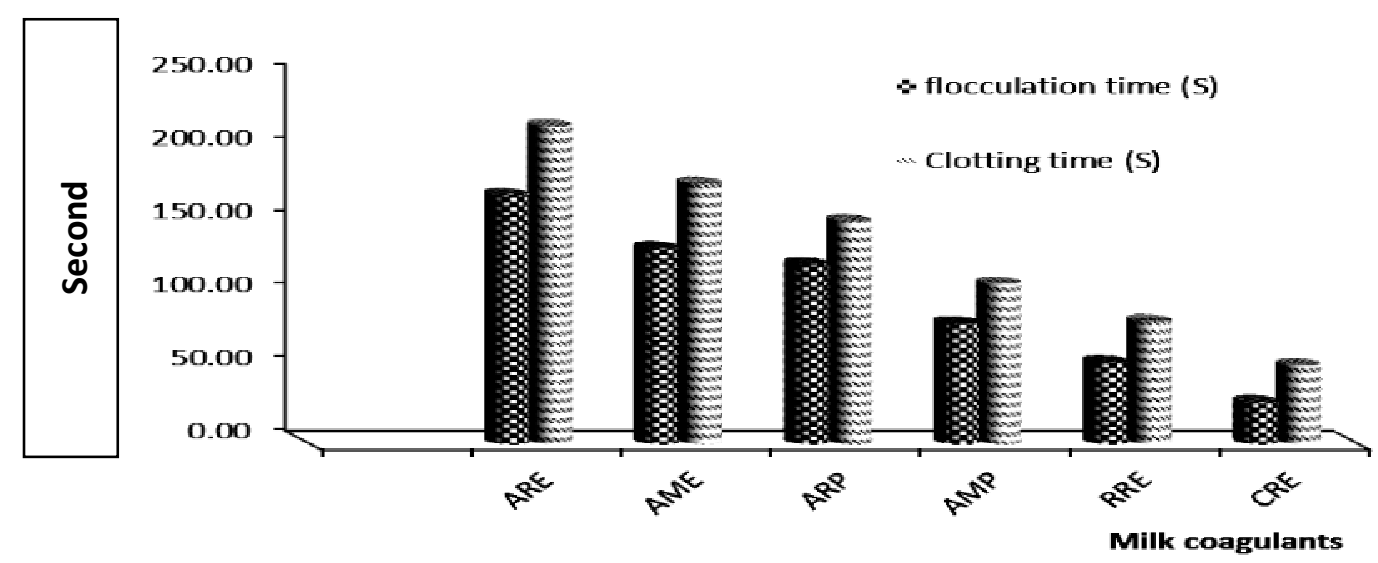

Fig. 1. Flocculation and clotting time of the different milk coagulants

ARE (Adult cattle rennet extract)

AME (mix of adult cattle rennet with Moringa seeds) ARP (partially purified of adult cattle rennet extract)
AMP (partially purified adult rennet mixed with Moringa seeds) RRE (commercial rennet )

CRE (calf rennet extract)

Table 1. Milk clotting properties of different milk coagulants

\begin{tabular}{|c|c|c|c|c|c|}
\hline $\begin{array}{l}\text { Milk } \\
\text { coagulant }\end{array}$ & $\begin{array}{c}\text { Protein content } \\
(\mathrm{g} / \mathrm{l})\end{array}$ & $\begin{array}{l}\text { Milk clotting } \\
\text { activity }(\mathrm{U} / \mathrm{ml})\end{array}$ & $\begin{array}{c}\text { Specific activity } \\
\text { (U/mg) }\end{array}$ & $\begin{array}{c}\text { Proteilytic } \\
\text { activity }(\mathrm{U} / \mathrm{ml})\end{array}$ & MCA/PA \\
\hline \multicolumn{6}{|c|}{ Crude extract } \\
\hline ARE & $1.53 \pm 0.05^{\mathrm{a}}$ & $110.74 \pm 4.91^{\mathrm{d}}$ & $72.54 \pm 3.37^{d}$ & $0.88 \pm 0.05^{\mathrm{d}}$ & $125.84 \pm 10.44^{\mathrm{d}}$ \\
\hline AME & $1.45 \pm 0.08^{\mathrm{ab}}$ & $135.44 \pm 8.40^{\mathrm{d}}$ & $93.54 \pm 6.80^{d}$ & $0.93 \pm 0.08^{d}$ & $145.63 \pm 6.14^{\mathrm{cd}}$ \\
\hline RRE & $1.31 \pm 0.03^{\mathrm{de}}$ & $288.22 \pm 23.76^{b}$ & $220.41 \pm 14.38^{b}$ & $0.47 \pm 0.05^{\mathrm{b}}$ & $613.23 \pm 20.95^{b}$ \\
\hline CRE & $1.27 \pm 0.03^{\mathrm{e}}$ & $455.71 \pm 79.23^{a}$ & $358.96 \pm 51.52^{\mathrm{a}}$ & $0.31 \pm 0.05^{\mathrm{a}}$ & $1470.03 \pm 346.64^{\mathrm{a}}$ \\
\hline
\end{tabular}

Partially purified extracts using aammonium sulphate precipitation

\begin{tabular}{llllll} 
ARP & $1.42 \pm 0.03^{\text {bc }}$ & $157.26 \pm 3.63^{\mathrm{b}}$ & $111.06 \pm 4.35^{\mathrm{d}}$ & $0.64 \pm 0.06^{\mathrm{d}}$ & $245.72 \pm 20.97^{\mathrm{cd}}$ \\
AMP & $1.36 \pm 0.05^{\mathrm{cd}}$ & $219.79 \pm 9.70^{\mathrm{c}}$ & $162.27 \pm 12.12^{\mathrm{c}}$ & $0.55 \pm 0.09^{\mathrm{c}}$ & $399.95 \pm 96.61^{\mathrm{bc}}$ \\
\hline
\end{tabular}

Means followed by different letters are significantly different at $\mathrm{P}<0.05$.

ARE (adult cattle rennet extract)

AME (mix of adult cattle rennet with Moringa seeds)

ARP (partially purified of adult cattle rennet extract)

MCA (milk clotting activity)

AMP (partially purified adult rennet mixed with Moringa seeds) RRE (commercial rennet)

CRE (calf rennet extract)

PA (proteolytic activity) sulphate of adult cattle rennet (ARP) without or with mixing with Moringa seeds increased the clotting activity of the resultant extracts approaching that of commercial rennet (RRE). There were significant differences $(p \leq 0.05)$ in milk clotting activity of crude and purified extracts. Similar results were reported by Purich (2010) and Lemes et al. (2016). The milk clotting properties are important both with regard to quality and yield of cheese. It has been submitted that a firmer curd at cutting is positively linked to yield of cheese (Wedholm et al., 2006).

Protein Content, Proteolytic Activity and Ratio Milk Clotting Activity (MCA) to Proteolytic Activity (PA)

Evaluation of enzymatic activities and proteolytic activities (PA) is a crucial step in the selection of an appropriate substitute of calf rennet. Table 1 shows the results of protein content, proteolytic activities (PA) and MCA/ 
PA for different milk coagulants. The protein contents $(\mathrm{g} / \mathrm{l})$ were $1.53,1.45,1.31,1.27,1.42$ and 1.36 for ARE, AME, RRE, CRE, ARP and AMP, respectively. There were significant differences $(\mathrm{P} \leq 0.05)$, between coagulants. However, an increase in protein content decreases milk clotting activity. In addition the results indicated that CRE was lower than ARE in proteolytic activity. This may be due to pepsin naturally present in rennet, which has a lower specific milk-clotting activity with a broader proteolytic activity than chymosin (Slamani et al., 2018). The breakdown depends on synergistic enzymatic action of chymosin and pepsin contained in animal rennet. The low proteolytic activity as shown in trials AMP followed ARP and AME are pre-requisite for an acceptable rennet substitute. The ratio of milkclotting activity (MCA) to proteolytic activity (PA) of the enzyme is a useful indicator for its quality as a rennet substitute for cheese making (Sánchez-Muñoz et al., 2017). The results clear that ARP and AMP extract had higher ratio (MCA/PA), in agreement with the findings of Barros et al. (2001). Therefore an enzyme with higher ratio of milk-clotting to proteolyic activity is able to form curd, get higher yield and less bitterness development during cheese processing. While, low ratio may developed lower curd recovery, weak curd firmness and release bitter peptides that affect the sensory properties of the final product (MazorraManzano et al., 2013). For this reason, the evaluation of enzyme activities and their comparison with commercial rennet is an important first step in choosing a suitable plant coagulant. From the results found, it can be concluded that, the milk clotting enzymes present in AMP, ARP and AME are promising candidates for application in industrial scale for production of cheese. Tajalsir et al. (2014) showed that partially purified enzyme from Moringa seeds showed higher ratio of milk clotting activity to proteolytic activity compared to that of calf rennet that is extensively used in cheese making industry.

\section{Optimum pH and Temperature for Milk- Clotting Activity}

The effect of $\mathrm{pH}$ and temperature on milk clotting activity is shown in Fig 2. Nearly all milk coagulants preparation; ARE, AME, ARP, AMP, RRE and CRE exhibited almost a linear milk clotting activity with an increased $\mathrm{pH}$ from 5.5 up to 6.5 . Milk clotting activity significantly enhanced at $\mathrm{pH} 5.5$ but activity was lowered above $\mathrm{pH}$ 6.5. Milk clotting activity decreased gradually as $\mathrm{pH}$ increased. The milk clotting activity of AME, ARP, AMP, RRE, and CRE was found to be high at $\mathrm{pH} 6.0$ and ARE at $\mathrm{pH}$ 6.5.These results agree with those of Tajalsir $\boldsymbol{e t}$ al. (2014), who used the same conditions. Furthermore, AME, RRE and CRE reached less activity up to $\mathrm{pH}$ 7.0. Also ARP and AMP showed complete inactivation up to $\mathrm{pH}$ 7.0. These results are in accordance with Elagamy (2000). Lamas et al. (2001) showed that most plant protease are unstable at alkaline $\mathrm{pH}$ value. Calf rennet showed similar conduct, acting better in acid $(\mathrm{pH}$ range of 5.5-6.0) than in alkaline reaction medium. The $\mathrm{pH}$ of the milk for rapid milk clotting activity is very important during cheese making. Ramet (2001) showed that all clotting cheese enzymes are acid protease, with optimum activity at $\mathrm{pH} 5.5$ and also that the kappa casein presents stability at $\mathrm{pH}$ 5.6. Lenoir et al. (1997) found that the effect of $\mathrm{pH}$ of milk on flocculation was very sensitive and apparent, thus the flocculation time is further reduced if the renneting $\mathrm{pH}$ is below the normal $\mathrm{pH}$ of milk. Formaggioni et al. (2001) reported that milk clotting properties were better when associated with decreasing values of $\mathrm{pH}$ and increasing values of titratable acidity.

On the other side, the influence of temperature was most pronounced between the $55-60^{\circ} \mathrm{C}$ for milk clotting activity of milk coagulants. Similarly (Kumari et al., 2012) reported that the purified serine protease (clotting enzymes) from Ficus religiosa had optimum temperature around $55-60^{\circ} \mathrm{C}$, but beyond these values there were a progressive denaturation of the enzyme and at $65^{\circ} \mathrm{C}$ there were no activity. The highest milk clotting activity was recorded for ARE, AME and ARP at $50-60^{\circ} \mathrm{C}$, and for AMP at 40 $-50^{\circ} \mathrm{C}, \mathrm{CRE}$ at $50-60^{\circ} \mathrm{C}$ and $\mathrm{RRE}$ at $55-65^{\circ} \mathrm{C}$. The temperature of maximum activity for milk coagulants AMP and CRE was $50^{\circ} \mathrm{C}$ likewise, milk coagulants ARE, AME and ARP was $55^{\circ} \mathrm{C}$ furthermore, milk coagulant RRE was $60^{\circ} \mathrm{C}$. The clotting activity began to decrease when temperature increased to $70^{\circ} \mathrm{C}$, which in the line 

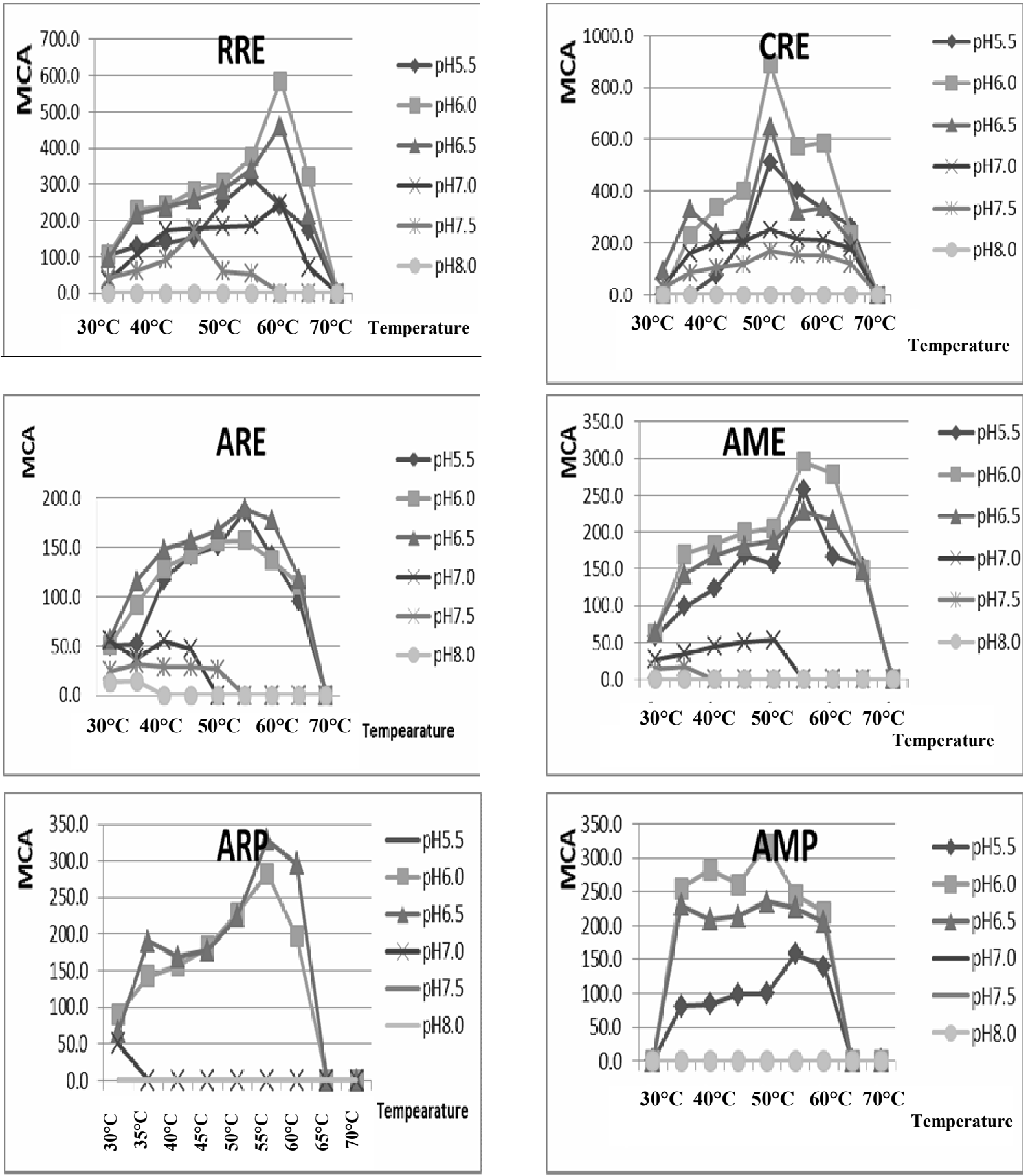

Fig 2. Optimum temperature and pH for milk-clotting activity of different milk coagulants

ARE (adult cattle rennet extract)

AME (mix of adult cattle rennet with Moringa seeds) ARP (partially purified of adult cattle rennet extract) MCA (milk clotting activity)
AMP (partially purified adult rennet mixed with Moringa seeds)

RRE (commercial rennet)

CRE (calf rennet extract) 
to the activity described by Ahmed et al. (2009). It is well known that the reaction rate of enzyme increases with increasing temperature, but after a certain temperature, the rate of reaction decrease due to denaturation and consequently the coagulation time is lengthened (Hashim et al., 2011). Shindo and Arima (1979) reported that cattle chymosin was relatively stable up to $50^{\circ} \mathrm{C}$ and a relative decline in the milk-clotting activity of almost $55 \%$ was observed at $55^{\circ} \mathrm{C}$, there being a total loss of activity at $60^{\circ} \mathrm{C}$. The optimum temperature of most clotting enzymes are around $40-50^{\circ} \mathrm{C}$, but further than these values there are a progressive denaturation of the enzyme and at $65^{\circ} \mathrm{C}$ there was no activity (Ramet, 1985). On the other hand, Balcones et al. (1996) reported that the decrease in clotting activity as a result of increasing temperature over certain limit could be explained by the changes in salt equilibrium and the complex between k-casein and $\beta$ - lactoglobulin.

\section{The Evaluation of the Rennet Curdling Quality}

The rennet curdling quality (RCQ) of crude extract, purified enzyme, commercial rennet and calf rennet is shown in Table 2. The curd formatted by CRE was very good and hard without separated whey. AMP had good hard curd, keeping its shape without appearing whey. However ARP had good curd, with little whey of yellow-greenish colour, RRE had hard curd, without appearing whey. AME, had softer creaminess curd, keeping its shape quite perfectly and whey was yellow. ARE, had, weak curd, not keep its shape, whey was milky white. In the same case Slamani et al. (2018), found that curd produced using ovine pepsin was less firm than that made with chymosin. Chymosin, an aspartyl proteinase, is used for coagulating of milk and fabrication of cheese. The results indicated that the best (RCQ) was found in the curd formatted by CRE followed by AMP, ARP and AME. Whilst, the worst (RCQ) was found in the curd shape by ARE coagulant. So, the curd formation from CRE coagulant exhibited the fastest and ARE had the lowest. Results from this study indicated that mix adult cattle rennet with Moringa seeds and its partially purified enzyme demonstrated the highest clotting activity compared with adult cattle rennet. These results are in agreement with those of Tajalsir et al. (2014).

\section{Electrophoretic Profile of the Curd Format by Different Milk Coagulants}

Fig. 3 shows SDS-PAGE of curd formed by ARE, AME, ARP, AMP, RRE and CRE extract. The applied electrophoretic method separated curd cheese proteins into multiple components with molecular weights ranged from $10 \mathrm{kDa}$ $250 \mathrm{kDa}$, values were similar to those reported by Manzo et al. (2017). There were notable differences in electrophoretic patterns among curds shaped by different coagulant extracts. All coagulant extracts hydrolysis $\kappa$-casein but in varying proportions. CRE coagulant characters appeared $\kappa$-casein. AME similar CRE had clear hydrolysis of $\kappa$-casein. On the other hand, there hydrolysis products $(\alpha, \beta$-casein) were found in curd cheeses made with AME coagulant. The results agree with those of García et al. (2012). Electrophoresis profile found that $\beta$-casein disappeared from curd formed by ARP curd. Partial purification from $M$. oleifera seeds (AMP) is a potentially useful tool in cheese production processes, since it did not promote extensive hydrolysis of $\alpha_{\mathrm{s}}$ - and $\beta$-caseins. This is in line with the results reported by Bruno et al. (2010). The result also found in ARE coagulant similar hydrolysis casein to that of AME coagulant. RRE coagulant had higher proteolytic activity against $\kappa$-casein than $\alpha$ - and $\beta$-casein (Ordiales et al., 2012)

\section{Physical Characteristics of Cheese Curd}

Physical characteristics of curd were assessed by determination of water release (WR) and water holding capacity (WHC).

\section{Water Release and Water Holding Capacity}

The results of water release (WR) and water holding capacity (WHC) of cheese curd are shown in Table 3. The results showed that CRE cheese curd had the lowest water release followed by AMP, RRE, ARP and AME, whilst, in turn, ARE had the highest $(p \leq 0.05)$, possibly 
Table 2. Evaluation of curdling quality (RCQ) clotting by different milk coagulants

\begin{tabular}{ll}
\hline Coagulant & Appearance, firmness of curd and appearance of whey \\
\hline ARE & Weak curd, partly liquefaction and loss of shape, whey milky white colour. \\
AME & Well curd but a softer creaminess, keeping its shape quite perfectly. \\
ARP & Good curd, a little whey, of yellow-greenish colour. \\
AMP & Good curd and hard, keeping its shape without appearing whey \\
RRE & Good curd and hard, without appearing whey. \\
CRE & Very good curd and hard, without separated whey. \\
\hline
\end{tabular}

ARE (Adult cattle rennet extract)

AMP (partially purified adult rennet mixed with Moringa seeds)

AME (mix of adult cattle rennet with Moringa seeds) RRE (commercial rennet)

ARP (partially purified of adult cattle rennet extract) CRE (calf rennet extract)

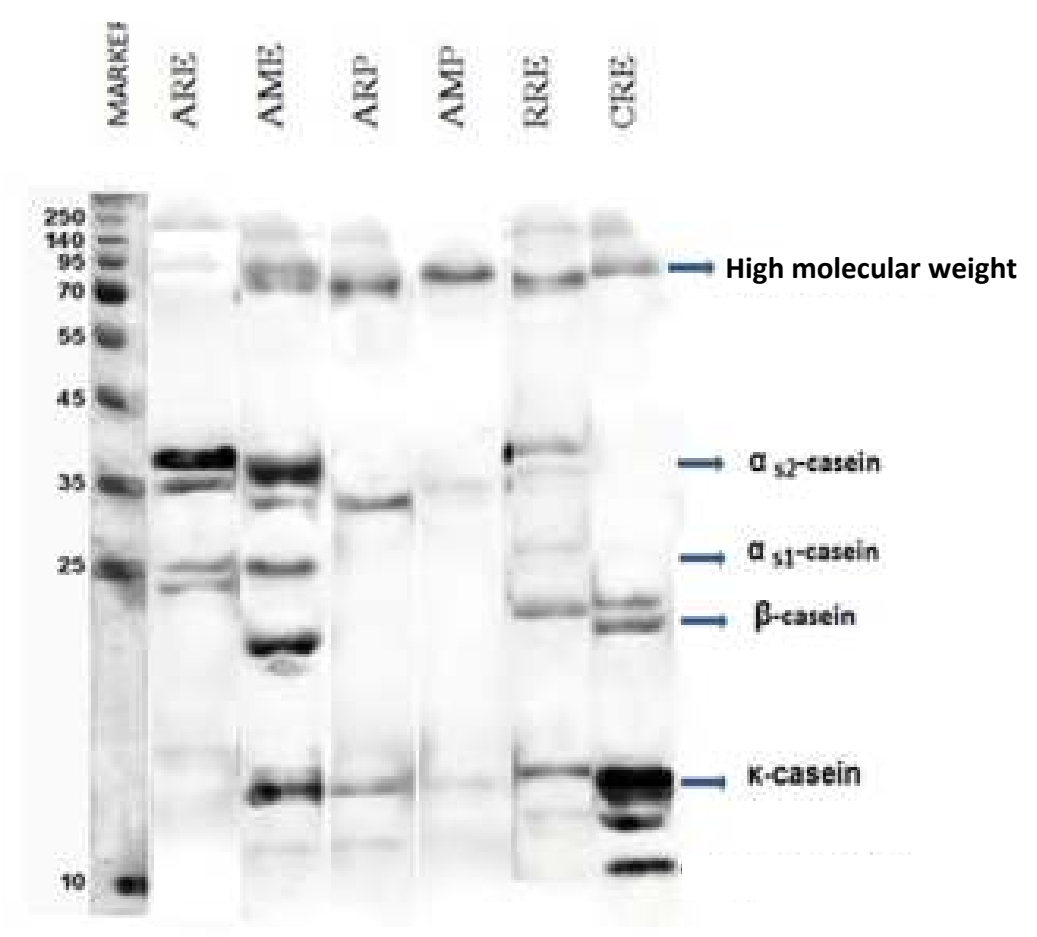

Fig. 3. SDS-PAGE profile of curd formed with different milk coagulants

ARE (Adult cattle rennet extract)

AME (mix of adult cattle rennet with Moringa seeds)

ARP (partially purified of adult cattle rennet extract)
AMP (partially purified adult rennet mixed with Moringa seeds)

RRE (commercial rennet)

CRE (calf rennet extract) 
Zagazig J. Agric. Res., Vol. 46 No. (3) 2019

Tables 3. Physical properties of Domiati cheese curd formed by different milk coagulants

\begin{tabular}{lcc}
\hline Coagulant & Water release (WR) & Water holding capacity (WHC) \\
\hline ARE & $77.10 \pm 2.07^{\mathrm{a}}$ & $23.43 \pm 2.97^{\mathrm{b}}$ \\
AME & $73.23 \pm 6.31^{\mathrm{ab}}$ & $27.27 \pm 6.62^{\mathrm{ab}}$ \\
ARP & $72.93 \pm 1.62^{\mathrm{ab}}$ & $27.65 \pm 1.35^{\mathrm{ab}}$ \\
AMP & $69.83 \pm 3.19^{\mathrm{b}}$ & $31.07 \pm 3.15^{\mathrm{ab}}$ \\
RRE & $70.17 \pm 3.91^{\mathrm{ab}}$ & $30.80 \pm 4.66^{\mathrm{ab}}$ \\
CRE & $68.97 \pm 2.60^{\mathrm{b}}$ & $31.87 \pm 2.95^{\mathrm{a}}$ \\
\hline
\end{tabular}

Means followed by different letters are significantly different at $\mathrm{P}<0.05$.

ARE (Adult cattle rennet extract)

AME (mix of adult cattle rennet with Moringa seeds)

ARP (partially purified of adult cattle rennet extract)
AMP (partially purified adult rennet mixed with Moringa seeds)

RRE (commercial rennet)

CRE (calf rennet extract) because of the porous and loose gel in ARE curd. This may be due to that chymosin has high specificity for the k-casein and pepsin has low specificity which affects the properties of the curd, such as firmness or softness (Walstra et al., 2005). Pepsin as a single coagulating agent is not preferred in cheese making because of its high proteolytic activity (Temiz et al., 2008). A decrease in the water release causes the syneresis process, which refers to the serum that is out from the gel structure and accumulates on the surface. An increase in the syneresis process was observed in the ARE, which can be verified by reduction the values of water holding capacity (WHC). This occurrence was more evident when the samples were estimated by centrifugation, indicating a greater water release from gel structure. These results were markedly, and it may depend on the more water release and nonstable structure. Syneresis is one of the most important processes in cheese-making because it directly affects cheese yield and quality through its effect on moisture, mineral and lactose content of curd .It is also imperative to cut the curd at an appropriate firmness so that syneresis takes place properly and loss of milk solids in the whey can be minimized (Bynum and Olson, 1982). There were significant differences $(\mathrm{P} \leq 0$. 05 ) between the coagulant activities obtained for crude ARE and CRE comparative of other milk coagulants. The results showed that CRE, AMP and RRE curd cheese samples had a higher (WHC). Per cent of (WR) and (WHC) of ARP and AMP gels was similar. The clots formed by milk coagulants; AME and ARP showed the same characteristics; stability and transparent whey exudate. These results showed that both the mix adult cattle rennet with Moringa seeds and partial purified enzyme could be used as alternative of commercial rennet.

\section{Yield and Sensory Evaluation of Fresh Domiati Cheese}

\section{Yield of cheese}

The casein fraction of milk protein is the dominant factor affecting curd firmness, syneresis rate, moisture retention, and ultimately affecting cheese quality and yield (Lawrence, 1993). Table 4 shows the yield of Domiati cheese made by different coagulants. It could be noticed that the cheese made by CRE had the highest yield, white cheese made by ARE had the lowest yield compared with cheese made by other coagulants. Furthermore, highly significant differences ( $\mathrm{p} \leq$ $0.05)$ were observed between all fresh cheeses except ARP similar AMP cheese. The speed of hydrolysis of caseins influences in yield, and slow degradation of $\alpha$ s-and $\beta$-caseins is guarantee production of a firm curd, which is occurs when chymosin is used (Bruno et al., 2010). Most rennet substitutes are more proteolytic than calf rennet and cause diminished yields of casein and fat. The increase in syneresis was probably due to the decreasing water holding capacity that led 
Table 4. Yield and sensory attributes of fresh Domiati cheese made from different milk coagulants

\begin{tabular}{lcccccc}
\hline Item & ARE & AME & ARP & AMP & RRE & CRE \\
\hline Yield & $15.86 \pm 0.65^{\mathrm{d}}$ & $16.86 \pm 0.05^{\mathrm{cd}}$ & $17.12 \pm 0.1^{\text {cd }}$ & $17.89 \pm 0.58^{\mathrm{bc}}$ & $18.48 \pm 0.93^{\mathrm{ab}}$ & $19.56 \pm 1.14^{\mathrm{a}}$ \\
& & & \multicolumn{5}{c}{ Sensory Properties } \\
Appearance (10) & $5.82 \pm 0.75 \mathrm{a}^{\mathrm{c}}$ & $6.91 \pm 0.70^{\mathrm{b}}$ & $7.60 \pm 0.74^{\mathrm{a}}$ & $7.73 \pm 0.47^{\mathrm{a}}$ & $8.00 \pm 0.78^{\mathrm{a}}$ & $8.30 \pm 0.82^{\mathrm{a}}$ \\
Flavour (50) & $44.27 \pm 1.49^{\mathrm{c}}$ & $46.87 \pm 1.49^{\mathrm{b}}$ & $46.30 \pm 1.16^{\mathrm{b}}$ & $47.55 \pm 1.04^{\mathrm{a}}$ & $46.55 \pm 1.13^{\mathrm{ab}}$ & $46.10 \pm 0.88^{\mathrm{b}}$ \\
Body and texture (40) & $34.45 \pm 2.81^{\mathrm{c}}$ & $35.36 \pm 1.29^{\mathrm{bc}}$ & $37.10 \pm 5.13^{\mathrm{ab}}$ & $37.40 \pm 1.73^{\mathrm{ab}}$ & $36.91 \pm 1.81^{\mathrm{ab}}$ & $38.30 \pm 0.68^{\mathrm{a}}$ \\
Overall scores (100) & $84.54 \pm 2.81^{\mathrm{c}}$ & $89.14 \pm 1.81^{\mathrm{b}}$ & $91.00 \pm 5.95^{\mathrm{a}}$ & $92.68 \pm 2.15^{\mathrm{a}}$ & $91.46 \pm 2.42^{\mathrm{a}}$ & $92.70 \pm 0.82^{\mathrm{a}}$ \\
\hline
\end{tabular}

Means followed by different letters are significantly different at $\mathrm{P}<0.05$.

ARE (Adult cattle rennet extract)

AME (mix of adult cattle rennet with Moringa seeds)

ARP (partially purified of adult cattle rennet extract)
AMP (partially purified adult rennet mixed with Moringa seeds)

RRE (commercial rennet)

CRE (calf rennet extract) to more release of whey. The whey drainage indicated weakness of the curd, probably decline the yield of cheese. Obviously, this submitted that Moringa seeds may have accounted for the increase in yield. These results are in agreement with the remark of Mahami et al. (2012) who used Moringa seeds in improving the yield and quality of cottage cheese. Results indicated that mixing adult cattle rennet with Moringa seeds or purified by ammonium sulphate resulted in decreasing the coagulation time, decreasing the curd syneresis and increasing the water holding capacity compared with adult cattle rennet only. Differences in the cheese yield among the different types of coagulants might be due to their proteolytic specificity, as highly specific coagulants provide higher cheese yields. Milk with short coagulation time, with lesser water retention and rise water holding capacity is expected to give more cheese yield (Kübarsepp et al., 2005).

\section{Sensory evaluation of cheese}

Sensory attributes included appearance, flavour, body and texture as well as overall scores of Domiati cheese made using different rennet sources are illustrated in Table 4. The results show that general acceptability of Domiati cheese as total scores indicated that CRE cheese gained the highest acceptability and that ARE cheeses gained the lowest scores being significantly ( $\mathrm{p} \leq 0.05$ ) different from other cheese treatments. Chymosin is the major enzyme of calf rennet, and it has been widely used in the dairy industry to produce a stable curd with good flavour due to its high specificity for the Phe105-Met106 bond of k-casein (Rao et al., 1998). Acceptability increased with mixing Moringa seeds and partial purification. Some studies reported that vegetable coagulants lead to a soft and pasty cheese texture, partly to liquefaction and loss of shape (Galán et al., 2008). As well as short peptides produced by its high proteolytic activity affect the flavour, which resulted in an excessively acidic and bitter cheese (Öner and Akar, 1993). On the present study appeared the status contradictory, the cheese made by used mix of adult cattle extract with Moringa seeds and partial purified had better sensory with characteristic; coherent texture and buttery taste. Tajalsir et al. (2014) reported that $M$. oleifera seed extracts were used as a milk-clotting agent, and the resulting curd was white and firm. The use of a low amount of plant coagulants in milk gelation at low $\mathrm{pH}$, may avoid the negative impact of excessive proteolysis of caseins on the texture and flavour of cheeses (Esteves et al., 2003). Generally cheese made by CRE had the higher overall scores followed AMP, RRE, ARP and AME. The results reveal that mixing Moringa seeds and its partial purification (by ammonium sulphate) are a new source of proteases with 
potential use for cheese making, since it promotes extensive hydrolysis of $\mathrm{k}$-casein and low degradation of $\alpha_{\mathrm{s}}$ - and $\beta$-caseins resulting. These results agree with Pontual et al. (2012). ARE cheese had the lowest scores; appearance, body and texture as well as flavour. Total sensory parameter of the cheeses clotting by mix Moringa seeds and purified enzyme were close to the RRE and of CRE cheese and both of them had higher sensory scores than ARE cheese.

\section{Conclusion}

Clotting studies are important in the manufacture and ripening of cheeses. Good milk-clotting enzyme is characterized by a high specific activity and a low proteolytic activity, later the proteolysis strongly affects the textural and sensory properties of cheese. However, a better understanding of the effect of plant coagulants on rheological properties, sensory characteristics (appearance, flavour, body and texture, taste as well as colour) in addition yield of the cheese is also of great importance when choosing the best substitute of calf rennet. This study focused primarily on maxing adult cattle rennet with Moringa seeds powder during extract processing to increase the rennet strength for milk clotting activity which effect on organoleptic scores and yield of cheeses. The characteristics of the final product could strongly resemble to those of the same cheese made with calf rennet.

\section{Acknowledgements}

The author would like to thank Dr. M.Z. ElAbbassy Professor of Food Science and Dairying, Food Science Department, Faculty of Agriculture, Zagazig University, for critically reading the manuscript.

\section{REFERENCES}

Abou-Donia, S.A. (1986). Egyptian Domiati soft white pickled cheese (Review) New Zealand. J. Dairy Sci. Technol., 21:167- 190.

Ahmed, I.A.M., I. Morishima, E.E. Babiker and N. Mori (2009). Characterisation of partially purified milk-clotting enzyme from Solanum dubium Fresen seeds. Food Chem., 116: 395- 400 .
Ahmed, G., S.A. Khan, M. Khaskheli, M.A. Qureshi and I. Ahmad (2013). Production and properties of rennet from buffalo calves abomasam. J. Anim. and Plant Sci., 23: 5-9

Akin, N. (1996). Peynir yapIminda kullanilan Süt Pihtilafltirici Enzimler ve Bunlarin Bazi Özellikleri. Gida, 21: 435-442.

AOAC (1995). Official Methods of Analysis', $16^{\text {th }}$ Ed. Association of Official Analytical Chemistry, Washington, DC, USA.

Badgujar, S.B. and R.T. Mahajan (2009). Proteolytic enzymes of some laticiferous plants belonging to Khandesh Region of Maharashtra, India. J. Pharma. Res., 2: 14341437.

Balcones, E., A. Olano and M.M. Calvo (1996). Factors affecting the rennet clotting properties of ewes milk. J. Agric. and Food Chem., 44 : 1993-1996.

Barros, R.M., C.A. Ferreira, S.V. Silva and F.X. Malcata (2001). Quantitative studies on the enzymatic hydrolysis of milk proteins brought about by cardosins precipitated by ammonium sulfate. Enzyme and Microbial Technol., 29:541-547.

Bodyfelt, F.W., J. Tobias and G.M. Trout (1988). The Sensory Evaluation of Dairy Products. Von Nostrand Reinhold, New York, 227-270.

Broome, M.C. and G.K.Y. Limsowtin (1998). Milk coagulants. Aust. J. Dairy Technol., 53:188 - 190 .

Bruno, M.A., C.M. Lazza, M.E.L. Errasti, L.M.I. López, N.O. Caffini and M.F. Pardo (2010). Milk clotting and proteolytic activity of an enzyme preparation from Bromelia hieronymi fruits. LWT-Food Sci. and Technol., 43: 695-701.

Bynum, D.G. and N.F. Olson (1982). Influence of curd firmness at cutting on Cheddar cheese yield and recovery of milk constituents. J. Dairy Sci., 65:2281-2290.

Çakmakçi, S. and E. Boroğlu (2004). Some quality characteristics of commercial liquid rennet samples. Turk. J. Vet. Anim. Sci., 28: 501-505. 
Castillo, M., F.A. Payne, C.L. Hicks, J. Laencina and M.B. López (2002). Effect of calcium and enzyme in cutting time prediction of coagulating goats' milk using a light scattering sensor. Int. Dairy J., 12 : 10191023.

Corrons, M.A., J.I. Bertucci, L. Constanza, L.M.I.L. López (2012). Milk clotting activity and production of bioactive peptides from whey using Maclura pomifera proteases. LWT- Food Sci. and Technol., 47: 103-109.

Elagamy, E.I. (2000). Physicochemical, molecular and immunological characterization of camel calf rennet: a comparison with buffalo rennet. J. Dairy Res., 67:73-81.

Esteves, C., J. Lucey, T. Wang and E. Pires (2003). Effect of $\mathrm{pH}$ on the gelation properties of skim milk gels made from plant coagulants and chymosin. J. Dairy Sci., 86: $2558-2567$.

Farnsworth, J.P., J. Li, G. M. Hendricks and M.R. Guo (2006). Effects of transglutaminase treatment on functional properties and probiotic culture survivability of goat milk yogurt. Small Ruminant Res., 65: 113-121.

Formaggioni, P., M. Malacarne, A. Summer, E. Fossa and P. Mariani (2001). Milk with abnormal acidity. VI. The role of phosphorus content and the rennet-coagulation properties of Italian Friesian herd milks. Parma, Italia, 21: 261-268.

Galán, E., F. Prados, A. Pino, L. Tejada and J. Fernández-Salguero (2008). Influence of different amounts of vegetable coagulant from cardoon cynara cardunculus and calf rennet on the proteolysis and sensory characteristics of cheeses made with sheep milk. Int. Dairy J., 18: 93-98.

García, V., S. Rovira, R. Teruel, K. Boutoial, J. Rodríguez, I. Roa and M.B. López (2012). Effect of vegetable coagulant, microbial coagulant and calf rennet on physicochemical, proteolysis, sensory and texture profiles of fresh goat's cheese. Dairy Sci. and Technol., 92: 691-707.

Guinee, T.P. and M. G. Wilkinson (1992). Rennet coagulation and coagulants in cheese manufacture. J. Soc. Dairy Technol., 45: 94104.
Hashim, M.M., D. Mingsheng, M.F. Iqbal and C. Xiaohong (2011). Ginger rhizome as a potential source of milk coagulating cysteine protease. Phytochem., 72: 458-464.

IDF (1993). Consumption Statistics for Milk and Milk products (1991). Bulletin No.282, Int. Dairy Ferment., Brussels, 1-3.

Irigoyen, A., J.M. Izco, F.C. Ibanez and P. Torre (2001). Influence of rennet milk-clotting activity on the proteolytic and sensory characteristics of an ovine cheese. Food Chem., 72: 137-144.

Kappeler, S.R., H.J.M. Van der Brink, H. Rahbek-Nielsen and Z.Z.F. Puhan (2006). Characterization of recombinant camel chymosin reveals superior properties for the coagulation of bovine and camel milk. Biochem. and Biophysical Res. Communications, 342: 647- 654 .

Kent, U.M. (1999). Purification of antibodies using ammonium sulfate fractionation or gel filtration. Methods in Molecular Biol., 115: $11-18$.

Kübarsepp, I., M. Henno, O. Kärt and T. Tupasela (2005). A comparison of the methods for determination of the rennet coagulation properties of milk. Acta Agric. Scand. Anim. Sci., 55 : 145-148.

Kuchtík, J., K. Šustová, T. Urban and D. Zapletal (2008). Effect of the stage of lactation on milk composition, its properties and the quality of rennet curdling in East Friesian ewes . Czech J. Anim. Sci., 53: 5563.

Kumari, M., A. Sharma and M.V. Jagannadham (2012). Religiosin B, a milk-clotting serine protease from Ficus religiosa. Food Chem., 131: 1295-1303.

Laemmli, U.K. (1970). Cleavage of structural proteins during the assembly of the head of bacteriophage T4. Nature, 227: 680-685.

Lamas, E.M., R.M. Barros, V.M. Balcao and F.X. Malcaia (2001). Hydrolysis of whey proteins by proteases extracted from Cynara cardunculus and immobilized onto highly activated supports Enzyme and Microbial Technol., 28:642-652. 
Lawrence, R.C. (1993). Relationship between milk protein genotypes and cheese yield capacity. In: Factors Affecting the Yield of Cheese. In: Emmons D. B. (Ed.). Int. Dairy Federation, Brussels, 121-127.

Lemes, A.C., Y. Pavón, S. Lazzaroni, S. Rozycki, A. Brandelli and S. J. Kalil (2016). A new milk-clotting enzyme produced by Bacillus sp. P45 applied in cream cheese development. LWT- Food Sci. and Technol., 66: 217-224.

Lenoir, J., F. Remeuf and N. Schneid (1997). Laptitude du lait à la coagulation par la pressure. In: André ECK, Gillis JC (Eds.), Le fromage Troisième. Tech Doc Lavoisier, France, 229-255.

Mahami, T., F.C.K. Ocloo, S.T. Odonkor, C. Owulah and S.A. Coffie (2012). Preliminary study on the influence of moringa seed extracts supplementation on the yield and quality of cottage cheese. Int. J. Recent Trends in Sci. and Technol., $2: 4-8$.

Manzo, N., L. Biondi, D. Nava, F. Capuano, F. Pizzolongo, A. Fiore and R. Romano (2017). On the possibility to trace frozen curd in Buffalo Mozzarella cheese. J. Food Res., 6 : 104-111.

Mazorra-Manzano, M.A., T.C. Perea-Gutiérrez, M.E. Lugo-Sánchez, J.C. Ramirez-Suarez, M.J. Torres-Llanez, A.F. González-Córdova and B. Vallejo-Cordoba (2013). Comparison of the milk-clotting properties of three plant extracts. Food Chem., 141: 1902-1907

Mehaia, M.A and S.M. El-Khadragy (1998). Physicochemical characteristics and rennet coagulation time of ultrafiltered goat milk. Food Chem., 62:257-263

Nelson, B.K., J.M. Lynch and J.M. Barbano (2004). Impact of milk preacidfication with $\mathrm{CO}_{2}$ on Cheddar cheese composition and yield. J. Dairy Sci., 87: 3581-3589.

Öner, M. and B. Akar (1993). Separation of the proteolytic enzymes from fig tree latex and its utilization in Gaziantep cheese production. LWT-Food Sci. Technol., 26: 318-321.

Ordiales, E., A. Martín, M.J. Benito, A. Hernández, S. Ruiz-Moyano and M.G.
Górdoba (2012). Technological characterization by free zone capillary electrophoresis (FCZE) of the vegetable rennet (Cynara cardunculus) used in "Torta del Casar" cheese-making. Food Chem., 133: 227-235.

Orhevba, B.A. and A.D. Taiwo (2016). Comparative assessment of wara (local cheese) produced using three natural additives as coagulants. Res. J. Food Sci. Nutr., 1: 49-55.

Papoff, C.M., R. Mauriello, A. Pirisi, G. Piredda, M. Addis and L. Chianese (2004). Proteolytic activity of animal rennet on ovine casein. Milchwissenschaft, 59: 414-417.

Pontual, E.V., B.E.A. Carvalho, R.S. Bezerra, L.C.B.B. Coelho, T.H. Napoleão and P.M.G. Paiva (2012). Caseinolytic and milk-clotting activities from Moringa oleifera flowers. Food Chem., 135: 1848-1854.

Purich, D.L. (2010). Factors Influencing Enzyme Activity. In D.L. Purich (Ed.), Enzyme Kinetics: Catalysis and Control-A Reference of Theory and Best-Practice Methods Elsevier.

Ramet, J.P. (1985). Study of enzymatic coagulation of camel milk in Saudia- Arabia. Mission Report, FAO, 1-73.

Ramet, J.P. (2001). The technology of making cheese from camel milk (Camelus dromedariue), N0.113, FAO, Rome, Italy

Rao, M.B., A.M. Tanksale, M.S. Ghatge and V.V. Deshpande (1998). Molecular and biotechnological aspects of microbial proteases. Microbiol. and Molecular Biol. Rev., 62: 597-635.

Sánchez-Muñoz, M.A., M.A. Valdez-Solana, C. Avitia-Domínguez, P. Ramírez-Baca, M.G. Candelas-Cadillo, M. Aguilera-Ortíz and E. Sierra-Campos (2017). Utility of milk coagulant enzyme of Moringa oleifera seed in cheese production from soy and skim milks. Foods, 6: 1-15.

Shah, M.A., S.A. Mir and M.A. Paray (2014). Plant proteases as milk-clotting enzymes in cheesemaking: A review. Dairy Sci. and Technol., 94: 5-16.

Shindo, K. and S. Arima (1979). Studies on chymosin: J. Chromatographic purification 
and some properties of chymosin. Agric. Biol. Chem., 28:A177-A180.

Silva, S., R. Barros and F. Malcata (2002). Hydrolysis of caseins by extracts of Cynara cardunculus precipitated by ammonium sulfate. J. Food Sci., 67: 1746-1751.

Slamani, R., R. Labadi, M.B. Errahmani and M.M. Bellal (2018). Purification and characterization of milk-clotting and caseinolytic activities of pepsin isolated from adult sheep abomasa. Int. J. Dairy Technol., 71:764 -770.

Tajalsir, A.E., A.S.A. Ebraheem, A.M. Abdallah, F.J. Khider, M.O. Elsamani and I.A.M. Ahmed (2014). Partial purification of milk-clotting enzyme from the seeds of Moringa oleifera. J. Microbiol. Biotechnol. Food Sci., 4 : 58-62

Temiz, H., E. Okumus and U. Aykut (2008). Partial purification of pepsin from turkey proventriculus. World J. Microbiol. Biotechnol., 24 : 1851-1855.

Vioque, M., R. Go'mez, E. Sanchez, C. Mata, L. Tejada and J. Fernandez-Salguero (2000). Chemical and microbiological characteristics of ewes' milk cheese manufactured with extracts from flowers of Cynara cardunculus and Cynara humilis as coagulants. J. Agric. Food Chem., 48 : 451-456.

Walstra, P., J.T.M. Wouters and T.J. Guerts (2005). Dairy Science and Technology. $2^{\text {nd }}$ Ed., CRC Taylor and Francis, Boca Raton, FL.

Wedholm, A., L.B. Larsen, H. LindmarkMånsson, A.H. Karlsson and A. Andrén (2006). Effect of protein composition on the cheese-making properties of milk from individual dairy cows. J. Dairy Sci., 89: 3296-3305. 
توصيف خصائص تجبن اللبن بمنفحة الماثية الكبيرة وتعديلها ببذور المورينجا لتكون بليلا مناسبا لمنفحة العجول الرضيعة في تصنيع الجبن المبند

\author{
هثام عبدالرحمن اسماعيل \\ قسم الألبان - كلية الزر اعة - جامعة الو ادى الجديد - مصر
}

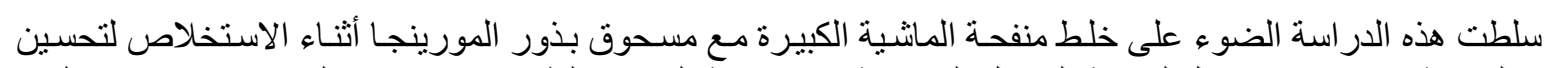

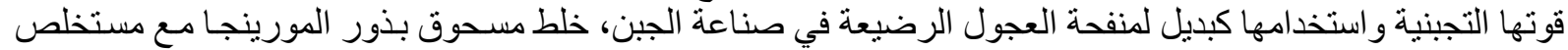

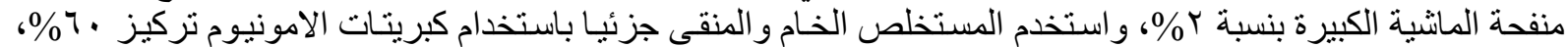

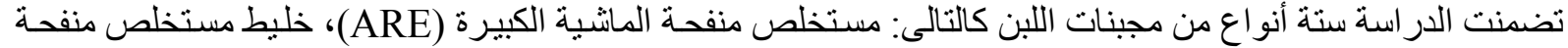

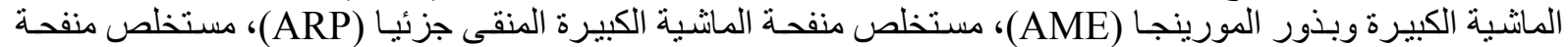

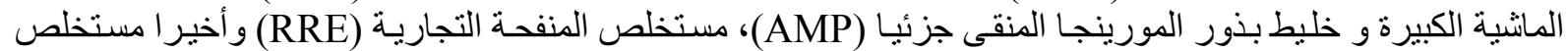

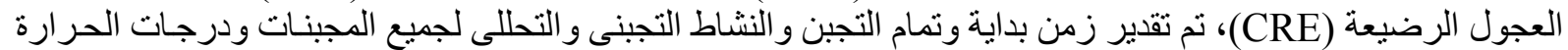

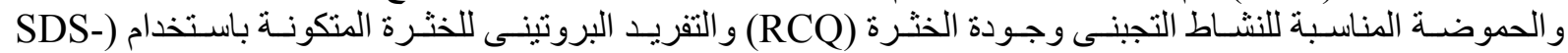

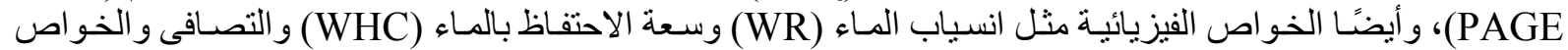

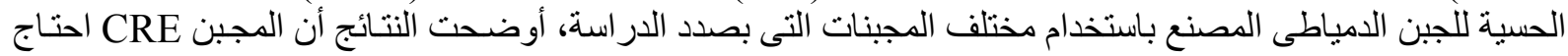

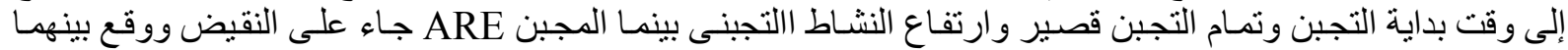

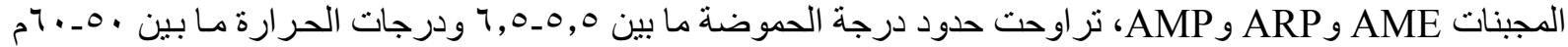

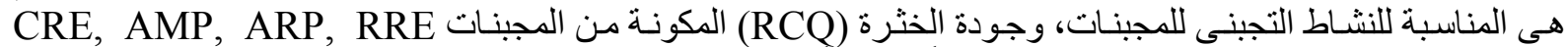
كانت أفضل و الخو اصن الفيزيائية أظهرت انخفاضاً ملحوظاً لانسياب الماء وارتفاع لسعة الاحتفاظ بالماء فى الخثرة المكونـة

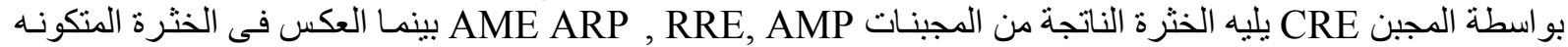

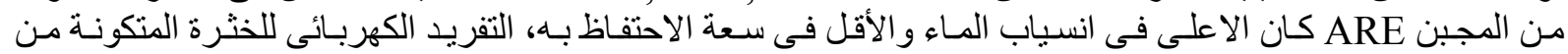

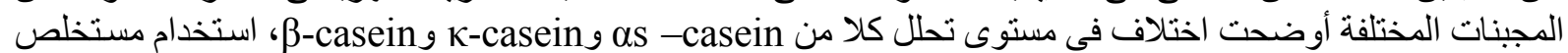

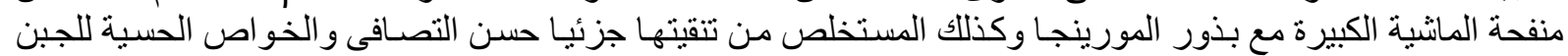

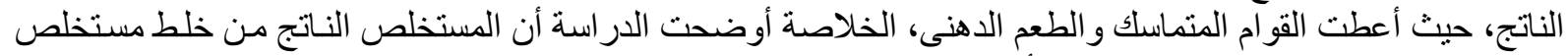

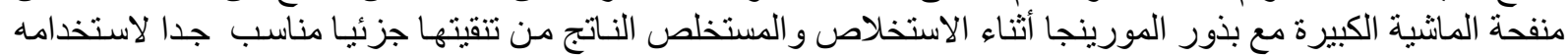
كبديلا لمنفحة العجول الصغيرة في صنئ صناعة الجبن. 